DOI:10.24193/tras.55E.5

Published First Online: 2018/10/23

\section{THE IMPACT OF THE ECONOMIC \\ CRISIS AND OBSTACLES TO \\ INVESTMENTS AT LOCAL LEVEL}

\section{Sunčana SLIJEPČEVIĆ}

\author{
Sunčana SLIJEPČEVIĆ \\ $\mathrm{PhD}$, Senior Research Associate, Department for Regional \\ Development, Institute of Economics, Zagreb, Croatia \\ Tel.: 00385-1-2362.234 \\ E-mail: sslijepcevic@eizg.hr
}

\section{Abstract}

The global economic crisis had a significant impact on the fiscal stance of local government units. The literature discusses this issue by explaining that financial crises change budget decisions of central state authorities towards the financing of those priorities which could improve the economic situation at national level. The impact of the change in national government's decisions influences local government units differently depending on the level of their fiscal autonomy. Investments at the local level are below pre-crisis levels in most European Union countries. This article analyzes the impact of the financial crisis on the fiscal imbalance showing that there is a lack of financial resources for investments. Due to fiscal constraints and annual borrowing limits of regional and local public administration authorities, the affordability of projects and investments is limited. Furthermore, the article analyzes the obstacles to investments at local level in Croatia, a country belonging to the group of European Union Member States which was hit hardest by the crisis and experienced a larger drop in investments. The results of the survey conducted among members of regional assemblies have been analyzed with respect to the level of local development and other factors enabling to identify more precisely the obstacles to investment.

Keywords: local government units, economic crisis, fiscal imbalance, development index, investment. 


\section{Introduction}

The purpose of this paper is to analyze the impact of the economic crisis on the fiscal stance of local government units and their possibilities to manage the local development policy and finance capital projects. The economic crisis that began in 2007 in the U.S. has been considered within the economic literature as the worst economic crisis since the 1930's and the literature suggests that, due to its depth and prolonged duration, its consequences could be felt for ten years (Levine, Justice and Scorsone, 2013). The global financial crisis has seriously deteriorated the fiscal position of governments in countries all over the world despite the level of their development. The general government deficit rose due to the lower collection of revenues, as well as the rising expenses for additional social spending which are needed to alleviate the crisis' effects (United Cities and Local Governments, 2009). Local economies were faced with rising unemployment, debt financing problems, business closures and bankruptcies, investment decrease, drop of property values, reduction of demand and others (OECD, 2009; Guidoum and Soto, 2010). Croatia entered the crisis in the period of unsustainable economic growth dependent on strong domestic demand, current account deficit, and credit growth (Bakker and Klingen, 2012). High vulnerability and rather low external competitiveness of the economy further narrowed the maneuvering space to reduce the impact of the crisis (Bakker and Klingen, 2012). The case of Croatia's deep and prolonged economic decline in the period 2008-2014 has shown that EU membership did not reduce exposure to recession, neither has it buffered the negative effects in the early membership phase.

The countries and, within them, different levels of government had at their disposal different approaches to fight crises. Clark's (2009) analysis of 41 local economies' responses on crises shows that they have conducted different types of measures. However, measures aimed at mitigating the effects of the recession at local level could not prevent consequences on unemployment (OECD, 2009) and, consequently, on revenues from income taxes (Jonas, 2012; Guidoum and Soto, 2010). Although most of the transition countries conducted reforms of transfer of expenditure authorities to local government, decentralization reforms where mostly proceeded by the method of trial and error and, in some cases, with the lack of appropriate transfer of responsibilities, which caused that some local public services sometimes remained the responsibility of the central government and vice versa (International Monetary Fund, 1998). Croatia, a country where the process of decentralization started in 2001, is not an exception. Jurlina Alibegović, Slijepčević and Kordej-De Villa (2013) stress that the decentralization reform in Croatia, in its first phase, was directed both to administrative and fiscal areas, but that the transfer of responsibilities was not accompanied by the adequate transfer of financial resources. Despite that, a significant part of public services remained under the control of local government units, while financial resources remained mostly under the control of the central government. Therefore, they could be easily affected by central state decisions. A similar problem of mismatch between local government responsibilities and financial resources has been noticed in some 
other European countries such as Germany, Sweden, and Austria (Pucher, Martinos and Schausberger, 2016). Eyraud and Moreno Badia (2013) analyzed the local government budgets in EU15 countries in the period 2001-2011 and concluded that in the first two years of the crisis (2008-2009) increases in local government expenses were financed from transfers from the central government, while in the subsequent two years (2010-2011) there was no further increase in central government transfers, but also in local government expenses. Their analysis also showed that in EU15 local government own revenues dropped during the crisis. Jonas (2012) discussed the fiscal impact of the 2007-2008 recessions on state and local governments in the United States and showed the high volatility of revenues from income taxes. He noticed that the fiscal response to recession depended on fiscal rules on borrowings.

Reviving investments became the top European Union priority and local government has an important role in it (Committee of the Regions, 2016). The level of investment in two-thirds of the European Union Member States, including Croatia, remained below pre-crisis level (European Commission, 2016; Committee of the Regions, 2016; Pucher, Martinos and Schausberger, 2016). The purpose of this paper is to examine the impact of the financial crisis on the fiscal stance of local government units in Croatia and their possibilities to finance capital projects which are necessary for local economic development. Researches about the regional impact of crises are rare. Since there has been noticed an alarming drop of public investment at local level in the European Union (Pucher, Martinos and Schausberger, 2016) and the European Commission (2016) stresses that the Member States should put efforts into identifying and removing obstacles to investment at regional and local level, the article analyzes obstacles to investment at the local level from regional councilors' perspectives in the country belonging to the group of European Union Member States which was hit hardest by the crisis and experienced a larger drop in investments. The paper focuses on members of regional assemblies due to the fact that they have an important role in fostering public investments, creating a proper environment for fostering private investments and ensuring sustainable development at local level.

The article consists of four parts. After the first introductory part, follows an analysis of fiscal stance of local government units in Croatia in the pre-recession and recession periods. In this part, the fiscal imbalance is analyzed in connection with the level of local units' development as measured by the development index. The analysis of regional councilors' attitudes toward possibilities and barriers to finance capital projects are provided in part three of this article. Part four summarizes the results and presents the main conclusions.

\section{Fiscal stance of Croatian local government units}

Even though the level of decentralization in Croatia is lower than in most of the other European Union countries, the very long recession, which started in the fall of 2008, had a significant impact on the local government. Most of the local government units in Croatia, in the pre-crisis period, enjoyed a relatively favorable fiscal stance, 
even though it has to be emphasized that it was mostly based on central government transfers to local government and not on own resources. In Croatia, local units use, for financing their tasks and investments, tax and non-tax revenues, grants (mostly from the state budget) and capital revenues. However, local government units can influence only the tax on the use of public areas and, partially, the non-tax revenues which are in fact revenues whose purpose is prescribed through special regulations, while they do not have influence on most of the other revenues (Jurlina Alibegović, Slijepčević and Kordej-De Villa, 2013; Slijepčević, 2014). Municipalities, towns, and counties can independently control the rate of certain types of revenues, but within the limits prescribed by the central government. They therefore have very limited local autonomy and, in spite of the decentralization process, the revenue side of the budget is still largely centralized and depends on decisions of the central government. The limitations of such policy could be especially perceived during recession.

The total budget of 576 local and regional self-government units has been decreasing since 2008. During the recession budgets of all levels of local units decreased, but mostly those of the cities and municipalities. In 2016, budgets of cities and municipalities were still below the 2008 level, while a slight improvement of counties revenues could be observed (Figure 1). Total sub-national revenues were 7.6\% lower in 2016 than in 2008.

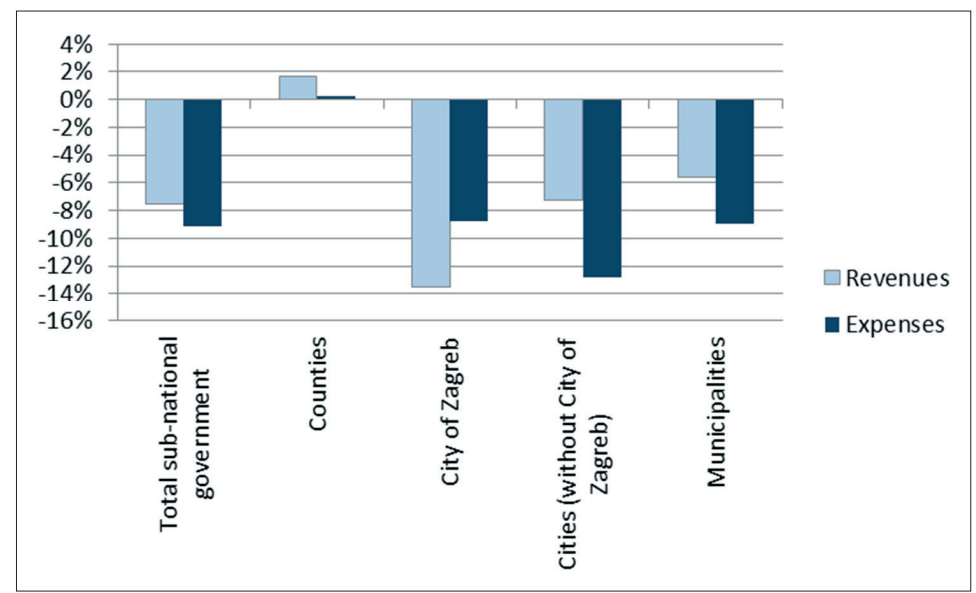

Figure 1: Change of the sub-national government budget in the recession period (2016/2008)

Source: Author's calculation based on the Ministry of Finance data

In this article fiscal imbalance is measured by two indicators. The first one is share of total local government units' revenues in total expenses. The second is share of local government units' revenues without grants in total expenses. Figure 2 shows that the level of fiscal imbalance continues to be higher than in the most favorable year of the pre-recession period (2007). Local government units' were confronted with the highest fiscal imbalance in 2009 when total revenues without grant covered only 
$78 \%$ of total expenses. In 2016, local government units' own resources were still lower than in 2008.

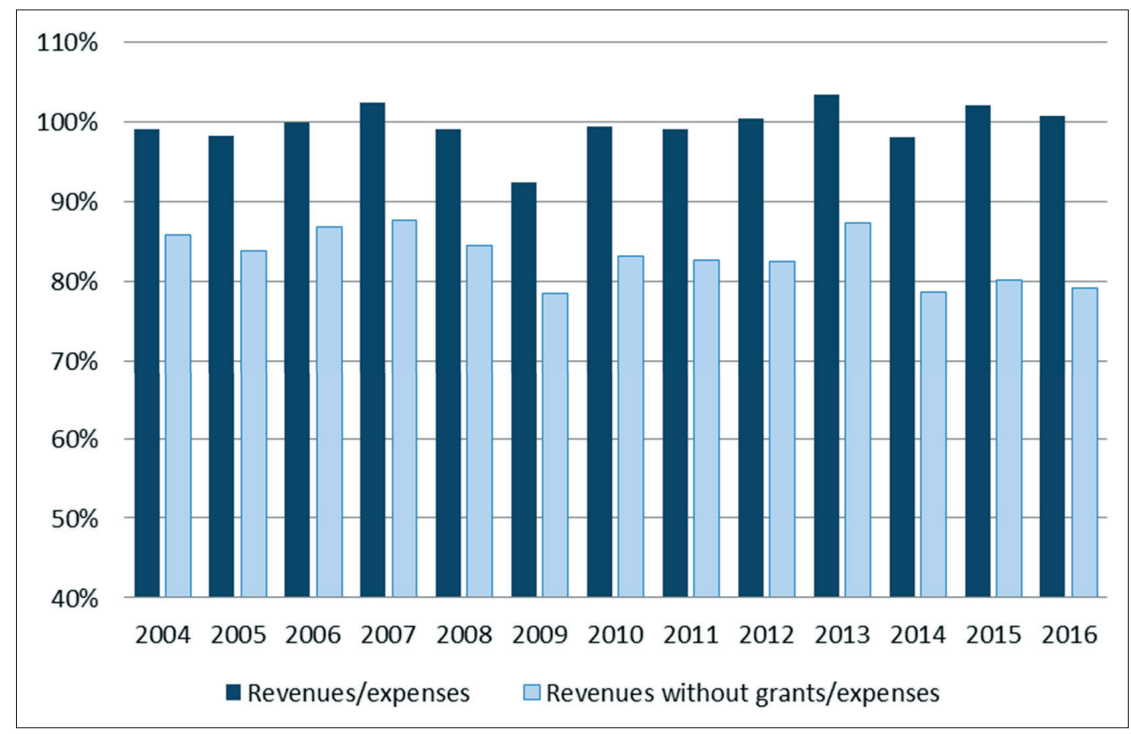

Figure 2: Local government fiscal imbalance

Source: Author's calculation based on the Ministry of Finance data

The financial crisis had a significant impact on the level and structure of local government budgets and influenced both sides of the budget (revenues and expenses), but also deteriorated the level of development of local government units.

The level of local development can be measured with the official local development index according to the Regulation on the Development Index from 2010. The local development index is calculated as a weighted average deviation from the national average of five socio-economic indicators. Those indicators are: unemployment rate ( $30 \%$ weight), income per capita ( $25 \%$ weight), local government revenues without grants, shared tax revenues from central government and surtax on income tax per capita (15\% weight), population ( $15 \%$ weight) and educational attainment rate (15\% weight). The local government index is calculated on the basis of data from the last three years or from census data. According to the level of development, counties could be distributed in the different groups based on the deviation of their development from the national average (Table 1).

Table 1: Categorization of counties according to the development index

\begin{tabular}{lc}
\hline \multicolumn{1}{c}{ Level of development index } & Number of counties in category, 2013 \\
\hline Less than $75 \%$ of national average & 12 \\
Between 75 and $100 \%$ of national average & 3 \\
Between 100 and $125 \%$ of national average & 3 \\
Above $125 \%$ of national average & 3 \\
\hline
\end{tabular}

Source: Ministry of Regional Development and EU Funds (2017) 
According to the NUTS system of classification, Croatia consists of the two NUTS2 units: (i) Adriatic Croatia, which consists of 7 counties, and (ii) Continental Croatia, which consists of 14 counties. The next two Figures present data about the impact of the financial crisis on local government units' resources and local development. Data imply that the development level in almost all local government units in Adriatic Croatia increased, while own resources in most of them decreased during the recession. The situation is even worse in Continental Croatia where both the level of development and fiscal capacity decreased during the recession in all counties, except in Karlovac and Zagreb counties, where the development index improved.

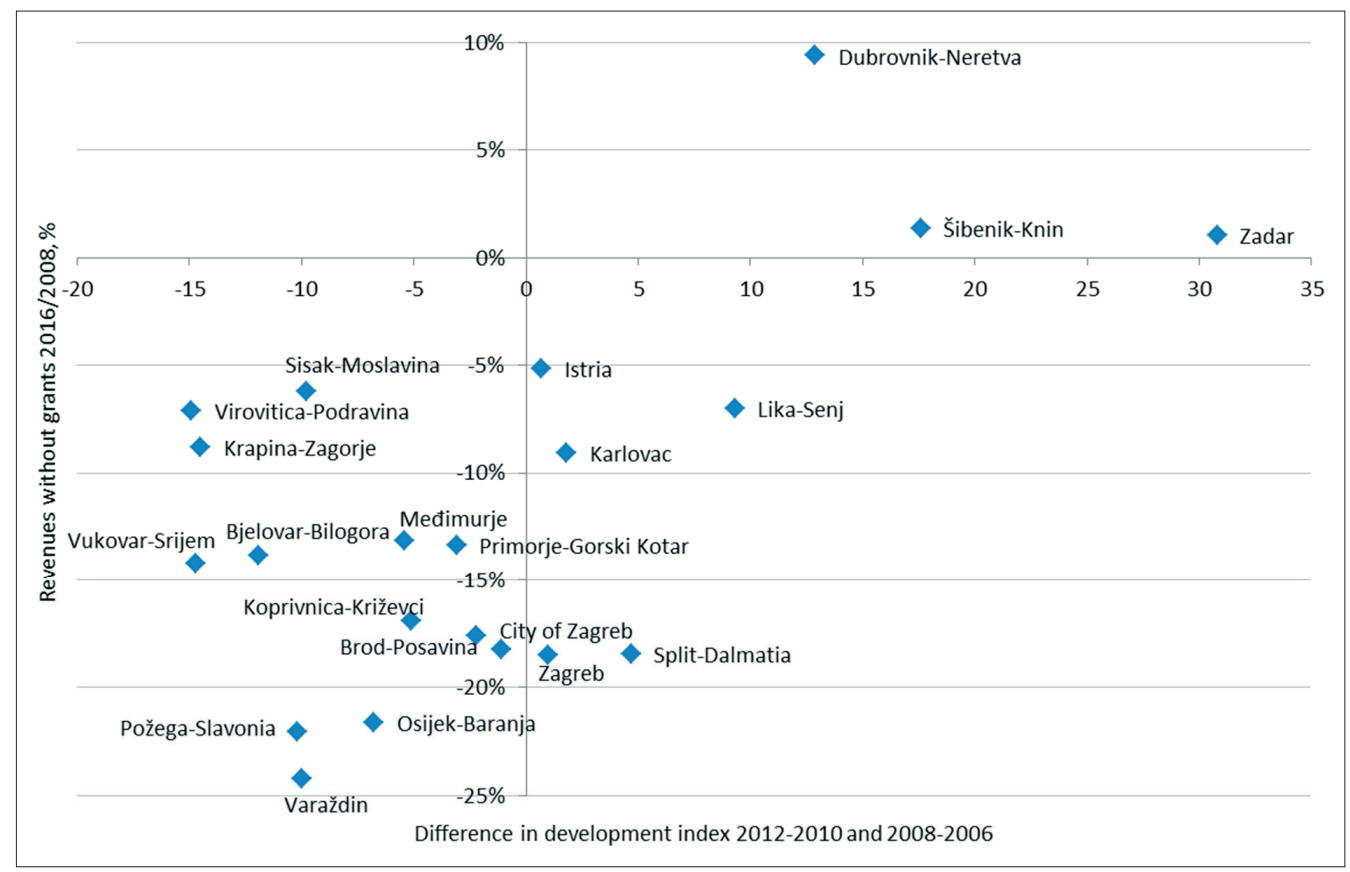

Figure 3: Impact of the financial crisis on own resources and local development

Source: Author's calculation based on the Ministry of Finance and Ministry of Regional Development and EU Funds (2017) data

Although one of the main goals of European regional policy is to decrease the regional disparities, the long-term financial crisis and the different consequences that it had on local government units in Croatia further widened the gap. The recession caused deepening of the imbalance in local government finances, as well as widening of the difference in their development dynamics (Slijepčević, 2014). Đokić, Fröhlich and Rašić Bakarić (2015) used panel growth regressions to investigate the influence of the economic crisis on regional disparities in Croatia and showed that average regional disparities increased during the 2008 recession.

The literature shows that the impact of the financial crisis on local government depends on many factors. Roitman (2009) claims that the impact of financial crises de- 
pends on the level of decentralization and that it is stronger in countries with lower level of decentralization. Davies, Kah and Woods (2010) claim that the crisis affected all regions to some extent, but it depended on the structure of economic activity. Their analysis shows that the crisis had the strongest impact on the structurally weaker regions and manufacturing regions. The impact of the crisis on the regional development policy was different across European countries depending on the response of national and regional authorities to the crisis. In some countries regional policy was used to respond to the crisis, while in others the crisis had led to cutting some components of infrastructure spending, which could have a negative effect on local economic development. Eyraud and Moreno Badia (2013) used econometric models on the period 1995-2011 to analyze to what extent subnational governments contributed to fiscal vulnerabilities in the EU15 countries. The result of their analysis showed that expenditure decentralization financed through transfers or borrowing, as it was mostly performed in the EU15 countries, lead to weaker fiscal outcomes. They state that a number of researches showed that local governments' propensity to spend intergovernmental transfers is significantly larger than the propensity to spend own resources.

The economic crisis put additional pressures on local governments. European Union countries which were harder hit by the crisis (Greece, Croatia, Italy, Latvia, Cyprus, Portugal, Spain, Finland, Slovenia, Denmark, Estonia, Hungary and Ireland) were mostly those who were experiencing larger decrease in investments (Committee of the Regions, 2016). So the purpose of this article is also to investigate more deeply the major problems for reviving investments in one country which was hit harder by the crisis (Croatia) due to the fact that its counties and local units within them require additional attention and help for recovering. The Council of European Municipalities and Regions (2015) warns that the European Union's financial rules (such as the rule of the Stability and Growth Pact, the Treaty on Stability, Coordination and Governance etc.), which have been introduced or modified since the beginning of the recession, strongly influence local governments and their budgets and thus they limit local authorities in undertaking investments.

\section{Methodology and results}

\subsection{Methodology and sample}

The previous sections of the article showed that the long recession had a significant impact of deepening the fiscal gap at local level. The purpose of this section is to examine the local councilors' opinions about the local government's budget and different options for financing projects.

Even though the process of decentralization in Croatia has begun more than 15 years ago, the degree of centralization has remained rather high. Local units perform mostly tasks related to environmental protection, housing and community improvement, recreation, culture and religion, and, to a lesser extent, other tasks (Bajo, 2014). Counties are responsible for the functions of regional character, which include per- 
forming certain tasks in the areas of education, health care, spatial planning, economic development, traffic and transport infrastructure, public roads maintenance, planning and development of the network of educational, medical, social and cultural institutions, issuing of building and location permits and other documents in relation to construction in the county area excluding the area of the big city and others. Regional assemblies in Croatia are each a regional self-government body which adopts the statute, decisions and acts within the scope of the county, carries out other tasks in accordance with the law and acts as a representative body of the citizens. The efficient performance of its tasks encourages local and regional development. Within their tasks regional assemblies also decide about cooperation with other local units in the Republic of Croatia and other countries, execute the budget, regulate county tax rates, establish public institutions, companies and other legal persons to conduct economic, social and other operations of interest to the county.

Research on the obstacles for investments at local level is based on the survey conducted among members of regional assemblies ${ }^{1}$ in Croatia during 2013. The questionnaire was developed in two steps. In the first step, the larger international questionnaire for councilors at regional level was developed by the group of researchers as part of the project 'Policy Making at the Second Tier of Local Government in Europe. What is happening in Provinces, Counties, Départements and Landkreise in the on-going re-scaling of statehood $?^{2}$. In the second step, additional questions necessary to get insight into their opinions about barriers to capital investments were formulated and added to the survey conducted in Croatia. The survey covered all Croatian counties. Councilors from all counties, except from the City of Zagreb, which has the status of town and county, answered the survey. The response rate was $36.9 \%$. The sample characteristics are shown in Table 2.

The questionnaire consists of 7 questions in the form of a statement where the answers were measured by 5-point Likert-scale, ranging from 1 (strongly disagree) to 5 (completely agree). The goal of these statements is to identify regional councilors' attitudes on the main obstacles for financing capital projects in Croatia and differences in their opinions. The analysis has been conducted using SPSS and Statistica softwares.

1 Local representative bodies are regional assemblies and the Zagreb City Assembly, as well as the municipal and city councils (Budgetary Act, 2008, 2012 and 2015).

2 A group of scholars, including the author of this paper, has developed a comprehensive survey consisting of around 270 questions, aimed at enabling the researchers involved in the survey to analyze the position of the second tier of local government in European countries from a comparative perspective. The survey has been conducted in Belgium, Croatia, the Czech Republic, England, France, Germany, Greece, Hungary, Italy, Norway, Poland, Romania, Spain and Sweden to investigate the attitudes of councillors at the second level of local government about democracy, public participation, administrative reforms etc. The original international survey has been expanded by further questions added only to the Croatian survey in order to analyze more deeply councillors' attitudes towards local economic development in Croatia. 
Table 2: Sample characteristics

\begin{tabular}{|c|c|}
\hline \multicolumn{2}{|r|}{ Sample characteristics } \\
\hline Number of analyzed regional councilors & 345 \\
\hline $\begin{array}{l}\text { Share of analyzed counties in the total } \\
\text { number of counties in Croatia }\end{array}$ & $95.2 \%$ \\
\hline $\begin{array}{l}\text { Share of regional councilors - respondents } \\
\text { in the total number of regional councilors }\end{array}$ & $36.9 \%$ \\
\hline $\begin{array}{l}\text { Structure of regional councilors - } \\
\text { respondents by NUTS2 }\end{array}$ & $\begin{array}{l}\text { Adriatic Croatia: } 31.0 \% \\
\text { Continental Croatia: } 69.0 \%\end{array}$ \\
\hline $\begin{array}{l}\text { Structure of regional councilors - } \\
\text { respondents by region }\end{array}$ & $\begin{array}{l}\text { Central Croatia: } 24.3 \% \\
\text { East Croatia: } 28.1 \\
\text { South Croatia: } 17.1 \% \\
\text { Istria and Primorje: } 17.4 \% \\
\text { South Croatia: } 13.0 \%\end{array}$ \\
\hline $\begin{array}{l}\text { Gender structure of regional councilors - } \\
\text { respondents }\end{array}$ & $\begin{array}{l}\text { Female: } 23.5 \% \\
\text { Male: } 71.3 \% \\
\text { Not answered: } 5.2 \%\end{array}$ \\
\hline $\begin{array}{l}\text { Structure of regional councilors - } \\
\text { respondents according to the education level }\end{array}$ & $\begin{array}{l}\text { Elementary school: } 0.9 \% \\
\text { Secondary school: } 37.4 \% \\
\text { University or higher education: } 57.7 \% \\
\text { Not answered: } 4.0 \%\end{array}$ \\
\hline $\begin{array}{l}\text { Age structure of regional councilors - } \\
\text { respondents }\end{array}$ & $\begin{array}{l}\text { Below } 40 \text { years: } 12.9 \% \\
40-49 \text { years: } 19.6 \% \\
\text { Above } 50 \text { years: } 60.8 \% \\
\text { Not answered: } 6.7 \%\end{array}$ \\
\hline $\begin{array}{l}\text { Political orientation of regional councilors - } \\
\text { respondents }\end{array}$ & $\begin{array}{l}\text { Left-wing: } 24.9 \% \\
\text { Center: } 36.3 \% \\
\text { Right-wing: } 28.9 \% \\
\text { Not answered: } 9.9 \%\end{array}$ \\
\hline $\begin{array}{l}\text { Structure of regional councilors - } \\
\text { respondents by development of their county }\end{array}$ & $\begin{array}{l}\text { Development index below } 75 \% \text { of national average: } 70.8 \% \\
\text { Development index between } 75 \text { and } 100 \% \text { of national average: } 5.6 \% \\
\text { Development index between } 100 \text { and } 125 \% \text { of national average: } 14.9 \% \\
\text { Development index above } 125 \% \text { of national average: } 8.8 \%\end{array}$ \\
\hline
\end{tabular}

Source: Author's analysis

The questionnaire consists of 7 questions in the form of a statement where the answers were measured by 5-point Likert-scale, ranging from 1 (strongly disagree) to 5 (completely agree). The goal of these statements is to identify regional councilors' attitudes on the main obstacles for financing capital projects in Croatia and differences in their opinions. The analysis has been conducted using SPSS and Statistica softwares.

\subsection{Survey results}

The analysis of survey results consists of several steps. The first step in the analysis was to assess which are the main obstacles for financing capital projects from regional councilors' perspective. The goal of the second step is to identify differences in their opinions and attitudes with respect to the different characteristics of the county (level 
of development of the county, NUTS2 classification, etc.) or respondent (gender, age and others). Differences in regional councilors' attitudes towards different obstacles were analyzed using the ANOVA and t-test.

Table 3: Regional councilors' attitudes toward obstacles for investments

\begin{tabular}{|c|c|c|}
\hline Obstacles for investments: & $\begin{array}{l}\text { Completely and } \\
\text { strongly agree }\end{array}$ & $\begin{array}{l}\text { Disagree and } \\
\text { fully disagree }\end{array}$ \\
\hline Lack of their own revenues; & $67.54 \%$ & $15.79 \%$ \\
\hline $\begin{array}{l}\text { Purpose of using non-tax revenues } \\
\text { prescribed by regulations; }\end{array}$ & $48.67 \%$ & $21.24 \%$ \\
\hline Weak tax collections; & $53.67 \%$ & $20.82 \%$ \\
\hline $\begin{array}{l}\text { Non-existence of necessary data and information } \\
\text { about how to apply for European Union funds; }\end{array}$ & $45.56 \%$ & $29.29 \%$ \\
\hline $\begin{array}{l}\text { Local government units' borrowing restrictions } \\
\text { which are prescribed by regulations; }\end{array}$ & $35.21 \%$ & $35.21 \%$ \\
\hline $\begin{array}{l}\text { Lack of transparent and sustainable system } \\
\text { of getting grants from central government; }\end{array}$ & $61.29 \%$ & $8.50 \%$ \\
\hline $\begin{array}{l}\text { Large competition between local government units } \\
\text { when they apply for borrowing approval. }\end{array}$ & $27.08 \%$ & $38.10 \%$ \\
\hline
\end{tabular}

Source: Author's analysis

The results show that most of the regional councilors find that counties are not able to finance capital projects from their own resources. The overall picture shows that most of the local units in European Union countries have a small share of own tax revenues in their total revenues, while the majority of resources comes as transfers from the central state authorities or from revenues on which local government has no influence (base or rate). Thus, it could be a large problem for local government units in other European Union countries as well. European Commission (2013), in the analysis of fiscal relations across government levels in the European Union during the economic crisis, stresses that a significant part of the deterioration in the fiscal position during the crisis occurred at the local level. However, they noticed that some local government units conducted the policy of waiting that the central governments cover the funding gap that occurred during the crisis because of the decrease of local government revenues. Besides increasing fiscal autonomy at the local level, the European Commission (2013) finds that it is equally important to introduce the performance-based transfer system.

More than $50 \%$ of regional councilors find that a transparent and sustainable system of getting grants from the central government is a necessary precondition for expense planning and planning borrowing on financial markets. In Croatia, a system of financing community needs has been designed in such a way that grants are used solely as funds to support local government units with poor fiscal capacity ${ }^{3}$. In add-

3 Every year the Law on the Execution of the State Budget prescribes the criteria for allocating grants to the local government units. 


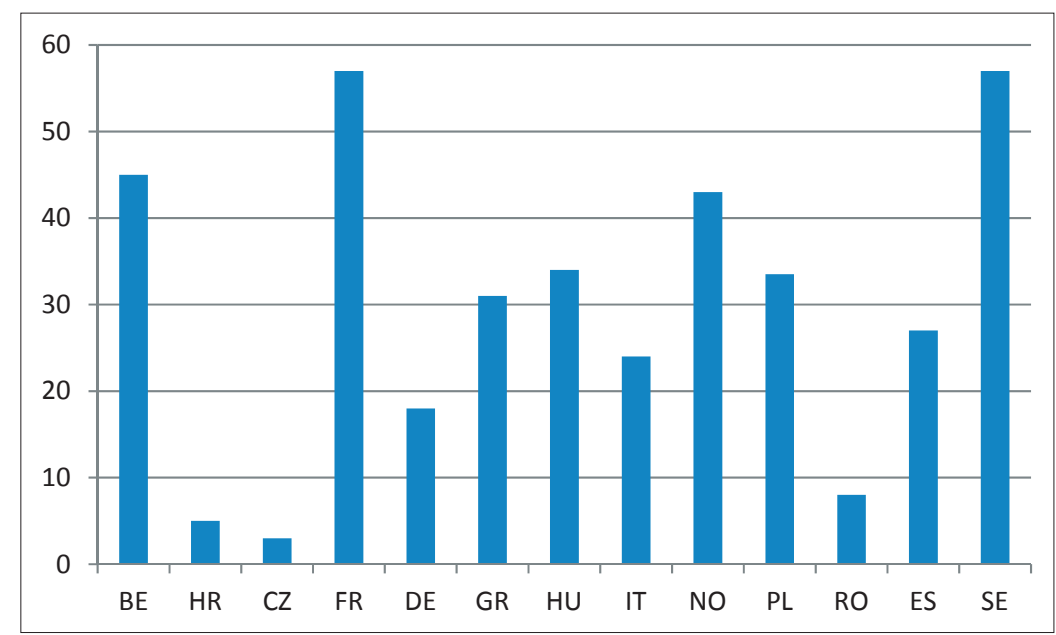

Note: BE - Belgium, HR - Croatia, CZ - Czech Republic, FR - France, DE - Germany, GR - Greece, HU - Hungary, IT - Italy, NO - Norway, PL - Poland, RO - Romania, ES - Spain, SE - Sweden, UK - United Kingdom.

Figure 4: Own tax revenues of sub-central government as $\%$ of the total local government revenue

Source: Eurostat and the survey

tion, equalization grants for decentralized functions are ensured from the state budget to cover public expenses in the area of primary and secondary education, social welfare and health care ${ }^{4}$.

As shown in the previous section, the financial crisis had a significant impact on local government budgets. Thus, it is not surprising that a weak tax collection rate has been seen, by $54 \%$ of regional councilors, as a significant obstacle for planning capital projects and borrowing. Apart from the aforementioned taxes and grants, local government units have introduced numerous other revenues on the basis of laws and/ or decisions of representative bodies, such as charges and fees, which are contained and stated in the non-tax revenues of their budget. The non-tax revenue is the autonomous revenue of sub-national government for which the purpose is set in advance. Sub-national government units independently set the rate of the non-tax revenue and independently carry out the collection of this revenue. The main non-tax revenue consists of municipal utility charges and contributions. These funds are used for the

4 Grant revenues from the state budget allocated to the counties, cities and municipalities which belong to the first and second category of special state concern. Grant revenues from the state budget allocated to the cities and municipalities for the personal income tax returns in the area of special state concern and in the hill and mountain areas. Grant revenues from the state budget allocated to the cities and municipalities for the profit tax returns in the area of special state concern and in the hill and mountain regions. Grant revenues from the state budget of other public bodies allocated to the cities and municipalities for the local development projects. Grant revenues from the state budget as equalisation fund allocated to the cities, municipalities and counties for financing decentralized functions. 
construction and maintenance of the utility infrastructure. This regulated purpose of using non-tax revenues is also seen as the large barrier for implementing capital projects in Croatia (by $49 \%$ of respondents).

General principles on local and regional government borrowing and borrowing restrictions prescribed by the Budgetary act has been seen as the least significant barrier for financing capital projects in Croatia. Local and regional self-government units may incur debt in two ways: borrowing by taking a loan or issuing securities (municipal bonds). All borrowing, guarantees and obligations, cannot exceed the maximum rate prescribed by law and presented in Table 4. A lack of transparency in fulfilling the criteria that must be met for getting the approval from the Government of the Republic of Croatia for issuing private or public debt by local units is the problem noticed within the literature dealing with public sector investment (e.g., Grubišić Šeba, Jurlina Alibegović and Slijepčević, 2014). Approvals for borrowings have been issued in the order of their submission until reaching the legally prescribed limits on borrowing. This means that approvals are granted according to the principle of the first-comer and not based on the quality of the project and this could be a barrier for financing capital investment projects.

Table 4: Conditions for local government borrowing

\begin{tabular}{ccc}
\hline Year & $\begin{array}{c}\text { Annual debt service limit } \\
\text { (annual commitment) }\end{array}$ & \multicolumn{1}{c}{ Additional restrictions } \\
\hline & & $\begin{array}{l}\text { Did not exist until 2002. From } 2003 \text { the boundary is prescribed on an } \\
\text { annual basis. From 2007 to } 2012 \text { was set at 2.3\% of realized current }\end{array}$ \\
$1998-2017$ & $20 \%$ of realized revenues & $\begin{array}{l}\text { revenues in the previous fiscal year of all Croatian local authorities. From } \\
2013 \text { it was increased to 2.5\% and in } 2017 \text { to } 3.0 \% \text { of outturn of current } \\
\text { revenues in the previous fiscal year of all sub-national government units. }\end{array}$ \\
\hline
\end{tabular}

Source: Author's compilation according to the data published in the Official Gazette

The goal of the second part of the analysis was to test the existence or non-existence of differences between the different groups of respondents. The survey data was analyzed using one-way analysis of variance (ANOVA) and t-statistics. One-way ANOVA was used to test the existence of differences in respondents' answers based on their age and political orientation, as well as the regional differences. In additional to the usual division of the country in two NUTS2 regions, to analyze more deeply cross-regional differences, the country was divided into five regions (Central, North, South, East Croatia, and Istria and Primorje). The literature suggests that such a division into five spatial entities for the purpose of such analysis is justified (Rajh, Budak and Anić, 2016). T-test was used to test the differences in the average scores between two groups of respondents (based on gender, level of development of their county and NUTS2). ANOVA and t-test results are presented in Table 5. 
Table 5: Analysis of differences

\begin{tabular}{lcccc}
\hline & Means & St.Dev. & N & ANOVA/t-test \\
\hline $\begin{array}{l}\text { Dependent variable: Lack of their own revenues } \\
\text { Independent variable: Age }\end{array}$ & & & & \\
\hline Less than 40 years old & 3.7 & 1.2 & 44 & $\mathrm{~F}=1.97$ \\
40-49 years old & 3.9 & 1.4 & 67 & $\mathrm{p}=0.14$ \\
Over 50 years old & 4.1 & 1.2 & 208 & \\
\hline Dependent variable: Lack of their own revenues & & & & \\
Independent variable: Development index & 4.1 & 1.2 & 261 & $\mathrm{t}=1.70$ \\
\hline DI 1 & 3.8 & 1.3 & 81 & $\mathrm{p}=0.09$ \\
\hline DI 2 & & &
\end{tabular}

Dependent variable: Purpose of using non-tax revenues prescribed by regulations Independent variable: Region

\begin{tabular}{llllll}
\hline Central Croatia & 3.6 & 1.2 & 82 & \\
East Croatia & 3.5 & 1.2 & 97 & \\
North Croatia & 3.1 & 1.1 & 57 & $\mathrm{~F}=2.34$ \\
Istria and Primorje & 3.6 & 1.2 & 60 & $\mathrm{p}=0.05$ \\
South Croatia & 3.6 & 1.2 & 43 & \\
\hline
\end{tabular}

Dependent variable: Purpose of using non-tax revenues prescribed by regulations Independent variable: Gender

\begin{tabular}{lcccc}
\hline Male & 3.6 & 1.2 & 244 & $\mathrm{t}=1.62$ \\
Female & 3.3 & 1.2 & 80 & $\mathrm{p}=0.10$ \\
\hline $\begin{array}{l}\text { Dependent variable: Weak tax collections } \\
\text { Independent variable: Development index }\end{array}$ & & & & \\
\hline DI 1 & 3.7 & 1.2 & 260 & $\mathrm{t}=0.12$ \\
DI 2 & 3.4 & 1.2 & 81 & $\mathrm{p}=0.12$ \\
\hline
\end{tabular}

Dependent variable: Weak tax collections

Independent variable: Region

\begin{tabular}{llllll}
\hline Central Croatia & 3.8 & 1.1 & 83 & \\
East Croatia & 3.7 & 1.2 & 97 & $\mathrm{~F}=1.85$ \\
North Croatia & 3.4 & 1.2 & 57 & $\mathrm{p}=0.12$ \\
Istria and Primorje & 3.6 & 1.3 & 60 & \\
South Croatia & 3.3 & 1.2 & 44 & \\
\hline
\end{tabular}

Dependent variable: Lack of necessary data and information about how to apply for European Union funds Independent variable: Political orientation

\begin{tabular}{lcccc}
\hline Left & 3.5 & 1.3 & 84 & $\mathrm{~F}=8.10$ \\
Centre & 3.0 & 1.2 & 124 & $\mathrm{p}=0.00$ \\
\hline Right & 3.7 & 1.3 & 99 & $\mathrm{P}$ \\
\hline
\end{tabular}

Dependentvariable: Non-existence of necessary data and information about how to apply for European Union funds Independent variable: NUTS2

\begin{tabular}{lllll}
\hline Continental Croatia & 3.5 & 1.3 & 234 & $\mathrm{t}=1.72$ \\
Adriatic Croatia & 3.2 & 1.4 & 104 & $\mathrm{p}=0.08$ \\
\hline
\end{tabular}

Dependent variable: Local government units borrowing restrictions which are prescribed by regulations Independent variable: Region

\begin{tabular}{lllll|}
\hline Central Croatia & 3.2 & 1.2 & 83 & \\
East Croatia & 3.2 & 1.3 & 96 & \multirow{2}{*}{$\mathrm{F}=2.91$} \\
North Croatia & 2.6 & 1.3 & 57 & $\mathrm{p}=0.02$ \\
Istria and Primorje & 3.3 & 1.4 & 59 & \\
\hline South Croatia & 3.0 & 1.3 & 43 & \\
\hline
\end{tabular}




\begin{tabular}{|c|c|c|c|c|}
\hline & Means & St.Dev. & $\mathbf{N}$ & ANOVA/t-test \\
\hline \multicolumn{5}{|c|}{$\begin{array}{l}\text { Dependent variable: Local government units borrowing restrictions which are prescribed by regulations } \\
\text { Independent variable: Age }\end{array}$} \\
\hline Less than 40 years old & 3.4 & 1.0 & 44 & \multirow{3}{*}{$\begin{array}{l}F=2.16 \\
p=0.11\end{array}$} \\
\hline 40-49 years old & 3.2 & 1.3 & 67 & \\
\hline Over 50 years old & 3.0 & 1.3 & 205 & \\
\hline \multicolumn{5}{|c|}{$\begin{array}{l}\text { Dependent variable: Lack of transparent and sustainable system of getting grants from central government } \\
\text { Independent variable: Region }\end{array}$} \\
\hline Central Croatia & 4.0 & 1.0 & 82 & \multirow{5}{*}{$\begin{array}{l}F=1.88 \\
p=0.12\end{array}$} \\
\hline East Croatia & 4.1 & 1.0 & 97 & \\
\hline North Croatia & 3.7 & 1.1 & 58 & \\
\hline Istria and Primorje & 3.8 & 1.1 & 60 & \\
\hline South Croatia & 3.7 & 1.1 & 44 & \\
\hline \multicolumn{5}{|c|}{$\begin{array}{l}\text { Dependent variable: Lack of transparent and sustainable system of getting grants from central government } \\
\text { Independent variable: NUTS2 }\end{array}$} \\
\hline Continental Croatia & 4.0 & 1.0 & 235 & $t=1.75$ \\
\hline Adriatic Croatia & 3.7 & 1.1 & 106 & $p=0.08$ \\
\hline
\end{tabular}

Source: Author's calculations

The results show that the lack of own revenues for financing capital projects is considered a larger problem by regional councilors from less developed counties (counties whose value of development index is lower than the national average). Younger regional councilors (less than 40 years old) find the lack of local government unit revenues to be larger barrier for capital investment than respondents older than 40 years. In addition, younger regional councilors consider that local government units' borrowing restrictions prescribed by regulations are larger barriers for investments than respondents older than 40 years.

The results show that regional councilors from different regions have different opinions about the prescribed purpose of using non-tax revenues. Councilors from North Croatia consider that the prescribed purpose of using non-tax revenues by regulations is a less important issue when considering the sources for financing capital investments than the other councilors.

Most of regional councilors find the lack of a transparent and sustainable system of getting grants from the central government as a barrier for capital investment. However, councilors from Continental Croatia find it a bigger barrier for investment. Also, the same opinions have councilors from Central and East Croatia.

The results confirm that weak tax collection is a bigger problem for financing longterm investments in less developed local government units. The analysis also shows statistically significant differences in answers of respondents from different regions about tax collection. Respondents from Central and East Croatia consider poor tax collection as a barrier for financing investments. This is in line with expectations, as local units with lower budgets are largely dependent on grants from the central government. On the other side, as noticed in Jurlina Alibegović, Slijepčević and KordejDe Villa (2014) local government units in Croatia are highly dependent on income 
tax imposed by a rate defined by the central government and on which they cannot have an influence. From 2016, according to the Law on Financing of Local and Regional Self-Government Units (Official Gazette 117/93, 69/97, 33/00, 73/00, 127/00, 59/01, 107/01, 117/01, 150/02, 147/03, 132/06, 73/08, 25/12, 147/14 and 100/15) income tax revenues are distributed among local units as follows: municipalities and cities receive $60 \%$ of income tax revenues generated in their area and counties receive $16.5 \%$. In addition, the income tax is distributed in a manner that distinguishes whether the municipality, city or county finances or not decentralized functions in selected public services including education, health care, social welfare and fire-fighting. The maximum amount for decentralized functions amounts to $6 \%$ (1.9\% for primary and $1.3 \%$ for secondary education, $0.8 \%$ for social welfare, $1 \%$ for health care and $1 \%$ for fire-fighting). Local government units can also receive equalization grant for decentralized functions (165 of personal income tax) and grants for co-financing projects financed from European funds (1.5\% of personal income tax).

Knowledge and data exchange and the sharing of best practices have been widely recognized as the important factors for increasing the absorption capacity of EU funds and almost half of councilors in Croatia recognized it as the problem. Right wing regional councilors find that this is a larger problem than the others. Also the results of the survey show that it is a larger problem for councilors from Continental than from Adriatic Croatia.

\section{Conclusions}

Global financial crises deteriorate the fiscal position at central and local level across European countries. Local government units' fiscal autonomy is rather low and the decentralization process in many countries has been stopped due to recession. Overlapping of spending functions across different levels of government and mismatch between local government responsibilities and allocated financial resources further aggravated the situation at local level.

The analysis in this paper aims to investigate the impact of recession on the level of local economic development and obstacles for investments in the post-crisis period. The survey has been conducted in Croatia, the European Union country which has been hit hard by long recession. This is the country whose local government units were faced with similar consequences of the crisis as the other European countries. Due to the crisis, the differences in local government units' levels of development have widened and the level of fiscal imbalance became worse than in the pre-crisis period in Croatia. The financial pressure on the local level of government has increased. Such a situation in Croatia is similar to that in other EU countries. Pucher, Martinos and Schausberger (2016) stress the significant drop in public investments at the local and regional level across the European Union and that both private and public investments remained at pre-crisis levels in most of the European Union countries, including Croatia. Countries which are hit harder by the crisis are those who were experiencing larger decrease in investments (Committee of the Regions, 2016). 
As stressed by Council of European Municipalities and Regions (2015), underinvestment in the long-term has a devastating impact on the sustainable development at the local and regional level.

The goals of the regional policy in Europe are aimed at reducing regional disparities and this need is even more pronounced after the crisis. The budgets of many local units are small, and the level of fiscal autonomy is such that it does not allow them to cover the operational expenses and investments. Given that the divergence between local government units further deepened, less developed local units are now in an even harder position than in the pre-crisis period. The results of the survey conducted among regional councilors show that there are two major obstacles to investment: the lack of own revenues and the lack of a transparent and sustainable system of getting grants from the central government. Both of these obstacles are consequences of the way decentralization has been implemented in Croatia. Fiscal decentralization has been implemented only partially and with the maintenance of a high level of central government control over tax revenues. The disadvantages were especially evident during the crisis, when the central government measures had mitigated the decline of central government revenue. Local units, on the other hand, had very limited maneuvering space to do the same and thus local budgets shrank. Administrative decentralization should be accompanied by fiscal decentralization that would allow local units to realize larger own revenues. This kind of decentralization has led to the deepening of differences between local units, as well as their slow recovery, as could be seen in Figure 3.

Investigating the variance in attitudes with respect to differences between the several groups of respondents enables to better identify the obstacles for investments from different angles. The results show that less developed local government units have larger problems with lack of own resources and weak tax collection than others. Also, in the policy attempt to revive investments at the local level, more focus should be placed on introducing a more transparent and sustainable system of getting grants from the central government and on increasing knowledge and exchange of data and information about how to apply for European Union funds for financing investments, especially in local government units in Continental Croatia.

\section{References:}

1. Bajo, A., 'The Effects of Decentralization in the Republic of Croatia on Economic and Fiscal Position of the Istrian Region' (in Croatian), Zagreb: Institut za javne financije, 2014.

2. Bakker, B.B. and Klingen, C.A., How Emerging Europe Came through the 2008/09 Crisis: An Account by the Staff of the IMF's European Department, Washington: IMF, 2012.

3. Budgetary Act, Official Gazette, 87/08, 136/12 and 15/15.

4. Clark, G., 'Recession, Recovery and Reinvestment: The Role of Local Economic Leadership in a Global Crisis', Local Economic and Employment Development (LEED Programme), Paris: OECD, 2009. 
5. Committee of the Regions, 'Results of the CoR Online Consultation on Obstacles to Investments at Local and Regional Level', Report, Secretariat of the Commission for Economic Policy (ECON), Unit C2, September 2016.

6. Council of European Municipalities and Regions, 'Reviving Local Public Investments: Flexibility is Needed in the Existing Rules of the Stability and Growth Pact', CEMR Position paper, Brussels, December 2015.

7. Croatian Bureau of Statistics, Census 2011, [Online] available at http://www.dzs.hr/ default_e.htm, accessed on April 5, 2017.

8. Davies, S., Kah, S. and Woods, C., 'Regional Dimensions of the Financial and Economic Crisis', European Policy Research Paper, no. 70, European Policies Research Centre, February 2010.

9. Đokić, I., Fröhlich, Z. and Rašić Bakarić, I., 'The Impact of the Economic Crisis on Regional Disparities in Croatia', 2016, Cambridge Journal of Regions, Economy and Society, vol. 9, no. 1, pp. 179-195.

10. European Commission, Fiscal Relations across Government Levels in Times of Crisis - Making Compatible Fiscal Decentralization and Budgetary Discipline, Economic papers 501, Brussels, Belgium, July 2013, [Online] available at http://ec.europa.eu/economy_finance/ publications/economic_paper/2013/pdf/ecp501_en.pdf, accessed on April 5, 2017.

11. European Commission, Communication from the Commission to the European Parliament, the Council, the European Central Bank, the European Economic and Social Committee, the Committee of the Regions and the European Investment Bank, Annual Growth Survey 2017, COM(2016) 725 final, 16.11.2016, Brussels.

12. Eyraud L. and Moreno Badia, M., 'Too Small to Fail? Subnational Spending Pressures in Europe', in European Commission, Fiscal Relations across Government Levels in Times of Crisis - Making Compatible Fiscal Decentralization and Budgetary Discipline, Economic papers 501, Brussels, Belgium, July 2013, pp. 24-55, [Online] available at http://ec.europa.eu/economy_finance/publications/economic_paper/2013/pdf/ecp501_en.pdf, accessed on April 5, 2017.

13. Grubišić Šeba, M., Jurlina Alibegović, D. and Slijepčević, S., 'Combating Fiscal Constraints for PPP Development', 2014, Managerial Finance, vol. 40, no. 11, pp. 1112-1130.

14. Guidoum, Y. and Soto, P., 'Cities and the Economic Crisis - A Survey on the Impact of the Economic Crisis and the Responses of URBACT II Cities', Paris: EU URBACT Report, 2010.

15. International Monetary Fund, 'Financial Crises, Causes and Indicators', World Bank Outlook, Washington D.C., May 1998.

16. Jonas, J., 'Great Recession and Fiscal Squeeze at U.S. Subnational Government Level', IMF Working Paper WP/12/184, Washington: IMF, July 2012.

17. Jurlina Alibegović, D., Slijepčević, S. and Kordej-De Villa, Ž., 'Can Local Governments in Croatia Cope with More Responsibilities', 2013, Lex Localis: Journal of Local Self-Government, vol. 11, no. 3, pp. 471-497.

18. Jurlina Alibegović, D., Slijepčević, S. and Kordej-De Villa, Ž., 'Regional Development and Decentralization - Two Options to Overcome Lack of Funding', 2014, Transylvanian Review of Administrative Sciences, no. 43E, pp. 146-167.

19. Levine, H., Justice, J.B. and Scorsone, E.A., Handbook of Local Government Fiscal Health, Burlington, USA: Jones \& Bartlett Learning, 2013. 
20. Ministry of Finance (Republic of Croatia), Local Government Units' Database, [Online] available at http://www.mfin.hr/, accessed on April 5, 2017.

21. Ministry of Regional Development and EU Funds, 'Calculation and Classification of Counties According to the Level of Development' (in Croatian), 2017, [Online] available at https://razvoj.gov.hr/o-ministarstvu/djelokrug-1939/regionalni-razvoj/indeks-razvijenosti/dosadasnji-izracuni-indeksa-razvijenosti/3741, accessed on April 5, 2017.

22. OECD, 'Coping with the Crisis at Local Level: Policy Lessons from the OECD Programme on Local Economic and Employment Development (LEED)', internal working document, CFE, OECD, 2009.

23. Pucher, J., Martinos, H. and Schausberger, W., 'Obstacles to Investment at Local and Regional Level', Report, Committee of the Regions, European Union, 2016.

24. Rajh, E., Budak, J. and Anić, I.D., 'Hofstede's Culture Value Survey in Croatia: Examining Regional Differences', 2016, Društvena istraživanjal Journal for General Social Issues, vol. 25, no. 3, pp. 309-327.

25. Regulation on Development Index, Official Gazette 63/10, 158/13.

26. Roitman, K., 'Impact of the Financial Crisis on Decentralisation Processes - Literature Review', Governance and Social Development Resource Centre, 2009, [Online] available at http://www.gsdrc.org/, accessed on April 5, 2017.

27. Slijepčević, S., 'The Impact of the Global Crisis on Fiscal Imbalance and Local Economic Development in Croatia', in Angelova, B., Jurlina Alibegović, D. and Redzepagic, S. (eds.), Contemporary Trends and Prospects of Economic Recovery, Nice, France: CEMAFI International, 2014, pp. 696-714.

28. United Cities and Local Governments, 'The Impact of the Global Crisis on Local Governments', October 2009, [Online] available at http://www.uclg.org/sites/default/ files/9225580315_(EN)_uclgcrisis(eng).pdf, accessed on April 5, 2017. 